\title{
最先端半導体表面洗浄の課題と展望
}

\author{
服 部毅* \\ 服部コンサルティング・インターナショナル＼cjkstart焉253-0061＼cjkstart神奈川県茅ケ崎市南湖 5-17-82
}

（2017 年 10 月 10 日受付；2017 年 12 月 9 日掲載決定）

\section{Most Advanced Semiconductor Surface Cleaning : Current Problems and Future Prospects}

Takeshi HATTORI*

Hattori Consulting International, 5-17-82, Nango, Chigasaki, Kanagawa, 253-0061 Japan

(Received October 10, 2017 ; Accepted December 9, 2017)

\begin{abstract}
With semiconductor-device geometry shrinking and becoming more complex, conventional aqueous cleaning/drying of semiconductor surfaces tends to collapse high-aspect-ratio nano-structures due to the surface tension of rinsing water. This is one of the most significant problems in leading-edge semiconductor manufacturing. Some current problems in the most advanced semiconductor surface cleaning and several possible solutions to overcome the shortcomings of water-based cleaning will be described and discussed with special emphasis on non-aqueous or dry wafer-surface cleaning technologies to prevent the pattern collapse problem. While semiconductor device geometry will scale down to 5-nm and below in the near future, completely different materials and device structures will be introduced in the semiconductor-device manufacturing. Larger diameter (450-mm) silicon wafers will also be employed in the future. There will be more research challenges and opportunities in developing innovative semiconductor surface cleaning and conditioning technologies for these future applications.
\end{abstract}

KEYWORDS : semiconductor, surface cleaning, pattern collapse, dry cleaning, $450 \mathrm{~mm}$ wafer

\section{1. は じめに}

現在，スマートフォン最新機種に搭載されているアプ リケーション・プロセッサは, $10 \mathrm{~nm}$ プロセスで製造さ れている ${ }^{1)}$ 。今年 $(2018$ 年) 中には, いよいよ念願の EUV (Extreme Ultraviolet：極端紫外線）リソグラフィの 量産導入が実現し, $10 \mathrm{~nm}$ の壁を乗り越えて $7 \mathrm{~nm}$ プロ セスを採用した最先端ロジックデバイスの生産がはじま るだろう ${ }^{1)}$

従来は, 加工寸法の微細化は, 単に比例縮小 (Scaling) することを意味したが, 最近は微細化すると かえって電気的特性が劣化してしまうようになり, これ を補うために，デバイス構造を変え，構成材料を替え て, 微細化による性能向上・低消費電力化, さらにはト ランジスタ当たりの製造コスト低減を継続させている。 デバイス構造の微細化, 回路パターンの高密度化・高

*E-mail : hattori@alumni.stanford.edu
集積化, 配線の多層化が進むにつれて, 製造プロセスも 複雑になり, 工程数も増え続けている。

一方では, 更なる微細化を回避するため, 集積回路を 垂直積層する 3 次元化の検討も行われ, すでに, 64 層 3 次元 NAND フラッシュメモリが市販され2), 100 層を超 える構造も開発されている。一方, 微細化による製造コ スト高騰を吸収するため, $\mathrm{Si}$ 基板を従来の $300 \mathrm{~mm}$ から $450 \mathrm{~mm}$ へと大口径化する検討も行われてきたが, 先進 企業は, 現在, $300 \mathrm{~mm}$ での超微細化を優先させてい る。

今までは, 污染の可能性のある材料を製造ラインへ導 入することは極力避けて来られた。しかし，デバイスの 微細化・高性能化を継続させるために, 周期律表中のす べての元素を検討対象とし, かつては重大な污染源とし て忌み嫌われていた重金属 $(\mathrm{Cu}, \mathrm{Co}, \mathrm{Ni}, \mathrm{Pt}$ など）や, 余りなじみのない元素 $(\mathrm{Hf}, \mathrm{Ru}, \mathrm{La}, \mathrm{Zr}$ など）も今や 使わざるを得なくなっている。

BEOL（Back End of Line, 配線工程）への多層 $\mathrm{Cu}$ 配 
線/Low-k（低比誘電率）層間絶縁膜の導入に続いて, FEOL（Front End of Line, トランジスタ形成工程）でも High-k (高比誘電率) ゲート絶縁膜/メタルゲートや 3 次元 MOS ランジスタである Fin FET (Field Effect Transistor）構造が導入された。

このため, 異種の新金属材料やそれを用いたプロセス 自体が重大な污染発生源となっている。半導体製造現場 では, パーティクル（異物微粒子）や金属不純物, 有機 物などの微小 (微量) な污染物質が, 半導体製品の歩留 まりや信頼性にますます大きな影響を及ぼすようになっ ている

このため, ウェーハ表裏両面, さらにはウェーハエッ ジ/ベベル（端面および周辺の傾斜部）からこれらの染 物物質を除去するための洗浄工程が, 歩留まり・信頼性 を左右する重要な工程として半導体製造プロセス中に繰 り返し登場している3

LSI の微細化が急速に進む中で, 比較的アスペクト比 の高いフォトレジストや回路パターンなどの脆弱な微細 構造が洗浄・乾燥時に倒壊してしまう現象がしばしば見 受けられるようになってきた ${ }^{3 \sim 6)}$ 。リンス液（主に純水） の表面張力による毛管力に微細構造が耐え切れなくなっ てしまったからである。このようなトラブルが, 先端半 導体製造において大きな問題として顕在化している。

本稿では，このようなウェット洗浄によるパターン倒 壊の現状の課題, および解決策を概観し, 非水洗浄の中 でも特に, 真空技術に関連あるドライ洗浄に重点を置い て解説する。次に, 将来展望として, 超微細化や Si ウ エーハ大口径化にともなう洗浄について考察する。な お, デバイス微細化に伴い, 純水はパターン倒壊以外に も様々な問題を抱えているが, 顕在化しつつある先端半 導体製造における純水の問題点とその対策については, 参考文献5）を, 全般的な先端半導体表面洗浄技術につ いては以前「表面技術」誌に執筆した解説記事6) を参照 されたい。

\section{2. 洗浄による回路パターンの倒壊}

LSI の回路パターンが微細化するにつれて, ウェット 洗浄時の $\mathrm{Si}$ 基板表面のエッチングや絶縁膜の膜減りな どの, いわゆるマテリアルロスがデバイス特性に多大な 影響を及ぼすようになってきた。洗浄による基板表面の マイクロラフネスの増加も同様である ${ }^{7,8)}$ 。いずれも微 細化により顕在化してきた問題であるが，これらに対処 するため, 薬液は希釈化/低温化の方向にある ${ }^{3 \sim 8)}$ 。薬液 の希釈化は, 薬液使用量の低減という点で, 環境保全上 からも望ましい。しかし, 希釈化/低温化により污染除 去効率は著しく低下してしまう場合が多い。これをカバ
ーするためにメガソニック（MHz 級の超音波）や 2 流 体ジェット・スプレー（液体とガスとの混相流の高速噴 霧）などの物理的補助手段を併用することになるが9, 10), 微細回路パターンへのダメージ（パターン癒着や倒壊, 更にはパターン飛散）が生じやすく, 微細化と共にプロ セス・ウィンドウは狭まる一方で, これらの物理的手段 の採用を中止せざるをえないケースが増加している。

純水中にガスを適量溶存させて超音波の音圧を緩和す ると同時に洗浄効率を向上させる検討も行われてい る ${ }^{10)}$ 。ダメージ (回路パターン倒壊) の危険を常にはら むメガソニック洗浄や 2 流体洗浄が超微細化プロセスで 再浮上できるか否かは今後の研究の進展次第であろう。

このような外部からの人為的な物理力によるパターン 倒壊に加えて, 洗浄に使用する薬液やリンス時に使用す る純水の表面張力により発生する毛管力によってウェー 八乾燥時にパターン倒壊が製造ラインで頻発するように なった 分野では以前から知られていた現象である。半導体分 野では, 初めは, 脆弱なフォトレジストのパターン倒 壊が問題として取り上げられたが, その後, FEOLの STI (Shallow Trench Isolation) 構造や DRAM（Dynamic Random Access Memory）の円筒状キャパシタ構造でも 問題となった。さらに最近になって BEOL の脆弱な多 孔質 Low-k 層間絶縁膜ダマシン構造でも顕在化してお り, 最先端製造ラインでは, 新たに導入された 3 次元卜 ランジスタ（Fin FET）のフィン構造のパターン倒壊が 大きな問題となっている（Fig. 1)。

先端ラインでは, 純水リンス後に, 表面張力が水の約 1/3であるイソプロピルアルコール（IPA）を液体のま ま吹きかけて乾燥する手法が採用されている。最近は IPA を昇温して用いることにより, 蒸発を速めてパター ン倒壊をさらに防止する傾向にある。この手法はウェー
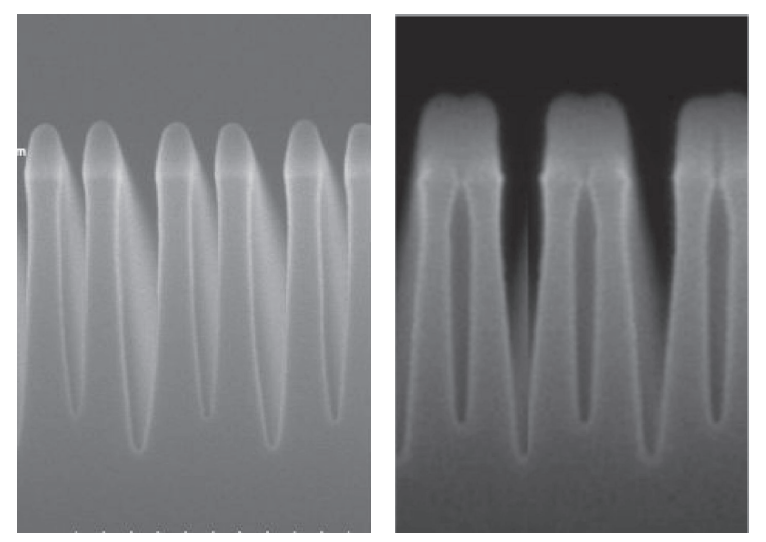

Fig. 1. Cross-sectional SEM images of high aspect-ratio fins of 3D fin FETs : a normal structure (left) and its collapsed feature (right). 


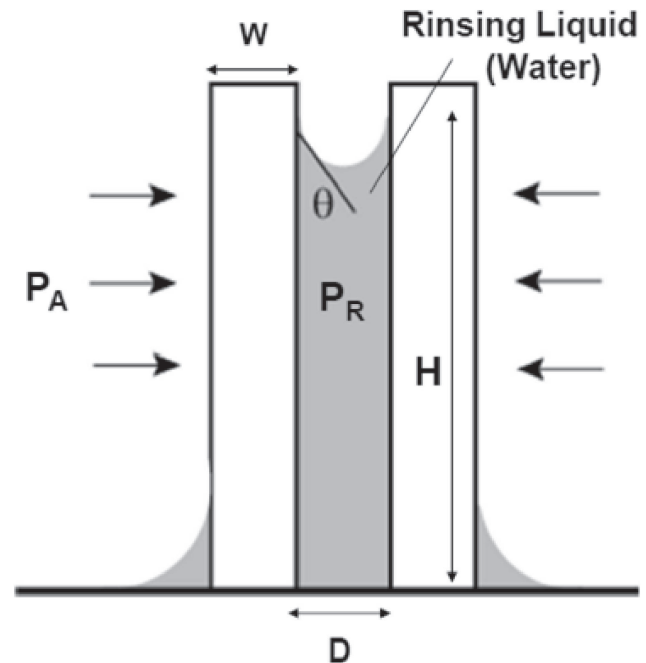

Fig. 2. Schematic drawing of two thin lines on a substrate during wafer surface drying after water rinsing.

ターマーク抑止にも有効である。しかし，最近は， 60 〜80 C のホットIPAを用いても高アスペクト比回路パ ターンの倒壊を防ぎきれず，この手法も限界に近付いて いる。

\section{1 パターン倒壊の材料力学的考察}

回路パターン倒壊の対策を述べる前に，ここでパター ン倒壊をもたらす水の表面張力に起因する毛管力につい て材料力学的な考察をしておこう ${ }^{11}$ 。微細な回路パター ンに見立てた 2 本の柱状構造物を薬液洗浄・純水リンス したあとに, 乾燥していく途中工程では Fig. 2 のよう に, 表面張力による毛管力で柱の間の狭い空間にリンス 液が残ってしまう状態となる。この場合, リンス液と空 気の圧力差に伴う力（毛管力）がリンス液面のみならず ラインパターン側面から作用する。すなわち, 空気側か らラインパターンが押されるようになる。パターン強度 がこの毛管力に耐えられなくなるとラインパターンは倒 れることになる。この毛管力 P は次式で与えられる。

$$
\mathrm{P}=\mathrm{P}_{\mathrm{R}}-\mathrm{P}_{\mathrm{A}}=\frac{2 \gamma \cos \theta}{\mathrm{D}}
$$

ここで $\mathrm{P}_{\mathrm{R}}, \mathrm{P}_{\mathrm{A}}$ はリンス液および空気の圧力， $\gamma$ はリン ス液の表面張力, $\mathrm{D}$ は回路パターンの幅, $\theta$ はリンス液 ・パターン境界（メニスカス）での接触角である。この 圧力は, パターンに曲げモーメントを生じさせる。そこ にかかる最大ストレス（最大曲げ応力） $\sigma_{\text {max }}$ は, 次式で 与えられる ${ }^{11)}$ 。

$$
\sigma_{\max }=3 \mathrm{P}\left(\frac{\mathrm{H}}{\mathrm{W}}\right)^{2}=\frac{6 \gamma \cos \theta}{\mathrm{D}}\left(\frac{\mathrm{H}}{\mathrm{W}}\right)^{2}
$$

ここで，H，W はそれぞれパターンの高さと横幅であ る。この $\sigma_{\max }$ が, 倒壊ストレス $\sigma_{\text {critical }}$ を越えるとライン パターンは倒壊する。

これをふまえて，パターン倒壊を防ぐ方法を考えてみ よう。 $\sigma_{\max }$ をできるだけ小さく（できればゼロに）する 方法として，次の 4 通りが考えられる。

1）ラインパターン幅 D を広げる。(これは，微細化に 反するので無理である。）

2）ラインパターンのアスペクト比 $(\mathrm{H} / \mathrm{W})$ を小さくす る。つまり, 高さ $\mathrm{H}$ を低く, あるいは幅 $\mathrm{W}$ を低く する。(これも，微細化に反するので無理である。)

3） $\cos \theta$ をさく，できればゼロにする。（以下の 2.2 参 照)

4）リンス液の表面張力 $\gamma$ を小さく，できればゼロにす る。(以下の 2.3 参照 $)$

\section{2 接触角を $90^{\circ}$ にする方法}

式 (2) で $\cos \theta=0$, つまり何らかの方法で接触角 $\theta$ を $90^{\circ}$ にできれば，ストレスはゼロになる。リンス液表 面をモノレイヤーの有機溶片で覆って接触角を最小化す る方法が提案されている ${ }^{12}$ 。液体 IPA を吹きかける方法 に比べて，パターン倒壊を $1 / 10$ 程度に軽減できたと言 うが，やはり複雑な微細パターンの倒壊は防ぎきれな ( ${ }^{11)}$ 。しかも，有機溶剂を使用するため, 有機污染によ

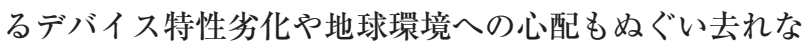
い。基板を疎水コーテイングする方法も同様である。後 で有機膜を除去するためウェット洗浄・リンスすれば, パターン倒壊してしまう。

\section{3 表面張力をゼロにする方法}

物質は, 温度と圧力に応じて固体・気体・液体とその 姿を変えるが, 温度と圧力をある值以上に高めると, 気 体と液体の特性を併せ持つ超臨界流体 (Super Critical Fuid）状態となり，原理的に表面張力が働かなくなる ${ }^{11)}$ したがって, 超臨界流体（実用的には, 臨界温度・圧力 が比較的低く毒性のない二酸化炭素 $\left.\left(\mathrm{CO}_{2}\right)\right)$ を用いれ ば, 式（2）で $\gamma=0$ となり, 微細パターン倒壊を完全 に防止することができる ${ }^{11}$ 。超臨界流体乾燥を用いると 微細な構造を機械的ストレス（界面張力）を加えること なく乾燥できる。半導体プロセスにおいても, フォトレ ジストだけではなく, FEOL の STI 構造や Cu/Low-k デ ユアルダマシン構造や次世代デバイスの超微細 3 次元構 造の洗浄・乾燥に向けた研究も行われてきた ${ }^{5 \sim 8,11,13,14) 。}$ MEMS 製造においては，すでに実用化している。

韓国 Samsung Electronics では, 1x-nm (20 nm 未満) クラスの最先端 DRAM の円柱状キャパシタのアスペク 卜比が 60 を超えており, もはや超臨界流体洗浄・乾燥 以に解がない状態になったため, 生産ラインに独自の超 
臨界乾燥技術を導入したと伝えられている ${ }^{15)}$ 。超臨界流 体技術の世界初の半導体量産工場での利用として注目さ れる。半導体プロセスに打ける超臨界流体洗浄・乾燥の 詳細については,「表面技術」誌に執筆した解説記事 14）や成書 11）を参照されたい。

\section{3. ドライ洗浄への期待}

ウェット洗浄の代わりに, 薬液や水を使わないドライ 洗浄（ドライクリーニング）を用いれば, パターン倒壊 は発生しない。それなら，すぐにでもウェット洗浄がド ライ洗浄に置き替わるかというと，そう簡単ではない。 半導体プロセスはドライ化が進み, 現在では多くの工程 でウェットエッチングがドライエッチングに押き替わっ ているが，ドライエッチング工程が増えれば増えるほ ど, 発生する反応副生成物や残渣除去のためにウェット 洗浄工程が増えるという皮肉な結果となっている ${ }^{3,4}$ 。

ドライ洗浄は，これまでウェット洗浄を補完する技術 として一部の工程で使われてきたが, ウェット洗浄の本 格的なドライ洗浄一の転換の見通しはいまだに得られて いない。Table 1 に, 半導体表面の主なドライ洗浄法を 示す。

なお，完全なドライな洗浄をガスフェーズ・クリーニ ング，水蒸気が反応に寄与するかあるいは生成するよう な厳密にはドライとは言えないような洗浄をべーパーフ エーズ・クリーニングといって区別する場合がある。

3.1 ドライ洗浄によるパーティクル除去

ウェット洗浄では。いわゆる RCA SC-1 洗浄（アンモ ニア/過酸化水素/純水混合液による洗浄) が最もパーテ イクルを除去できる洗浄として世界中で広く使われてい る る $^{3,4}$ 。しかし, 特定のガスとの化学反応のみで組成不 明のパーティクルをすべて除去することは不可能である し, 物理的手法で除去しようとするとパターンダメージ が生じやすい。

Table 1. Summary of dry wafer-surface cleaning methods.

\begin{tabular}{|c|c|}
\hline Contamination & Semiconductor Surface Dry-Cleaning Method \\
\hline \multirow[t]{2}{*}{ Particles } & $\begin{array}{l}\left.\text { Cryogenic aerosol spray (Solid } \mathrm{N}_{2}\right) \\
\text { Gas cluster ion beam irradiation }\left(\mathrm{CO}_{2}\right) \\
\text { Laser beam irradiation (Femto-sec. laser) } \\
\text { Nano-probe sweeping/Nano-tweezers pickup }\end{array}$ \\
\hline & $\begin{array}{l}\mathrm{UV} / \mathrm{O}_{3}\left(\text { or } \mathrm{UV} / \mathrm{O}_{2}\right) \\
\mathrm{O}_{2} \text { plasma }\end{array}$ \\
\hline Particles & $\begin{array}{l}\mathrm{UV} / \mathrm{Cl}_{2}\left(\text { or } \mathrm{UV} / \mathrm{Cl}_{2} / \mathrm{SiCl}_{4}\right) \\
\mathrm{UV} / \mathrm{F}_{2} / \mathrm{O}_{2} \\
\text { Volatile organic metal (chelate complex) formation } \\
\mathrm{HCl} \text { oxidation/anneal (at high temperature) }\end{array}$ \\
\hline Native Oxide & $\begin{array}{l}\mathrm{HF} \text { vapor }\left(\mathrm{HF} / \mathrm{H}_{2} \mathrm{O} \text { or } \mathrm{HF} / \text { Alcohol) }\right. \\
\mathrm{UV} / \mathrm{F}_{2} / \mathrm{H}_{2} \\
\mathrm{NF}_{3} / \mathrm{H}_{2} \text { or } \mathrm{NF}_{3} / \mathrm{H}_{2} \mathrm{O} \text { or } \mathrm{NF}_{3} / \mathrm{NH}_{3} / \mathrm{H}_{2} \text { plasma } \\
\mathrm{HF} / \mathrm{NH}_{3} \text { (at elevated temperature) } \\
\mathrm{H}_{2} \text { anneal (at high temperature) }\end{array}$ \\
\hline
\end{tabular}

パーティクル除去のためのドライ洗浄法としては, 極 低温エアロゾルスプレイ法が広く知られている3 ${ }^{3,4,8,16)}$ 固体二酸化炭素（いわゆるドライアイス）や固体 $\mathrm{Ar}$ を 用いると回路パターンや MEMS 構造にダメージを与え る場合でも，固体 $\mathrm{N}_{2}$ を用いると粒形をより小さくする ことができるため, ダメージを与えず洗浄できる ${ }^{16) 。 さ ~}$ らに粒径を小さくするために, ガスクラスターイオンビ 一ムを用いる方法も研究されている ${ }^{17)}$ 。

ウェー八全面をクリーニングするのではなく, 局在す るパーティクルだけをピンポイントで除去する方法とし て，レーザーをウェー八表面に照射して瞬間的な局所熱 膨張によりパーティクルを跳ね飛ばす方法 ${ }^{18)}$ や AFM の ナノプローブによる掃引, 微小な MEMS ピンセットで ピックアップする方法などが提案されている 5 万7, 19)。

\section{2 ドライクリーニングによる薄膜状污染除去}

離散したパーティクル以外の金属，有機物，自然酸化 膜などの薄膜状污染物質は, ガスを用いた化学的気相ク リーニングで除去することが可能である。ディスプレイ 用ガラス基板表面の有機污染除去に使われている UV/ $\mathrm{O}_{3}$ （または $\mathrm{O}_{2}$ ）は $\mathrm{Si}$ ウェー八にも有効である。金属污 染除去には UV $/ \mathrm{Cl}_{2}$ や UV $/ \mathrm{F}_{2} / \mathrm{O}_{2}$ など紫外線下でガスを 用いる方法のほか, 有機浴媒を用いて金属不純物を揮発 性有機金属（キレート）化する方法, 高温で $\mathrm{HCl}$ 酸化/ アニールする方法などが知られている。

酸化膜除去には, 無水 HF ガス/水蒸気（あるいはア ルコール蒸気）が広く使われている 去には, リモートプラズマ下で $\mathrm{NF}_{3} / \mathrm{NH}_{3} / \mathrm{H}_{2}$ 混合ガスを 用いる方法が Siconi の名称で知られている。これは, ト ランジスタの電極の電気抵抗を下げるために Si と Co あ るいは Ni などの金属との化合物であるシリサイドを形 成する前の $\mathrm{Si}$ 表面のドライ洗浄を指す造語である。こ のほか, $\mathrm{NF}_{3} / \mathrm{H}_{2} \mathrm{O}$ や $\mathrm{NF}_{3} / \mathrm{H}_{2}$ 混合ガスを用いる方法, あ るいはプラズマを用いずに昇温 $\mathrm{HF} / \mathrm{NH}_{3}$ を用いる方法, 紫外線照射下で $\mathrm{F}_{2} / \mathrm{H}_{2}$ ガスを用いる方法や高温水素アニ ールなどの方法があげられる ${ }^{3,4)}$

\section{3 ドライ洗浄の長所と問題点}

ドライ洗浄，とりわけ反応性ガスを用いた化学的気相 クリーニングの長所としては,

1）ガスを用いるので, 微細な溝や穴への反応種の侵入 が容易であり，均質な処理が期待できる

2）薬液や水を用いないので（反応副生成物として $\mathrm{H}_{2} \mathrm{O}$ が, 回路パターンの溝を埋めるほど大量に発生しな (限り), パターン倒壊の心配がない

3）反応生成物は強制的に排気されるので, 污染の再付 着が少ない (バッチ浸漬洗浄に比べて)

4) もともとドライなので, 乾燥工程が不要で, ウェッ 
ト洗浄で問題となるウォーターマークの発生やパ夕 ーン倒壊の心配がない

5）減圧下のプロセスであれば，クラスターッール内で 次の成膜工程との連続処理が容易である

6）液体と比べてガスの使用量が少なく, 廃棄物も低減 できる

などがあげられる。しかし，化学的気相クリーニング法 には, 次のような欠点があり, なかなか実用化しない原 因となっている。

1）除去対象の污染物質を揮発性物質に変化させ除去す る手法であるため, 揮発しない反応副生成物や残渣 が生じやすい。これをウェット洗浄で除去するのは 容易だが，ドライ洗浄で揮発・除去することは極め て困難である。以前なら無視できた極微量の残渣も, デバイスが微細化るに従い無視できなくなってきて いる

2）パーティクルを除去できない。真空装置内でのプラ ズマ処理では, むしろ多数のパーティクルを発生す る場合が少なくない

3）プラズマを用いると, 基板に対するダメージや 2 次 污染の心配がある

4）真空装置を用いた減压下でのドライクリーニング (やドライエッチング) の際に，ガスがウェー八表面 に凝結付着し, 後に空気中の水分と徐々に反応して $\mathrm{HCl}$ や $\mathrm{HF}$ などの蒸気が発生し, 集積回路上の金属 配線の腐食を引き起こすだけではなく, ウェー八表 面の曇りやパーティクルの原因となる。基板表面か ら脱離した分子状污染物質は, 近隣のウェーハや FOUP (Front Opening Unified Pod) 内面に付着し, さらに被害を広がることがある20)

ドライ洗浄は, 真空技術を利用する場合が多く, 今後 は真空技術者の協力を得て上述した問題点を克服して, 将来, さらに広く活用されるようになることを願ってい る。

\section{4. $5 \mathrm{~nm}$ 未満超微細化にむけた洗浄の課題}

Intel は, $45 \mathrm{~nm}$ プロセスから「40 年ぶりのトランジ ス夕構成材料の大変革」と称して, 永らく慣れ親しんで きた Si 酸化膜・窒化膜/ポリ Si ゲート構造から High-k (高誘電率) 膜/メタルゲート構造に変更し, 他社も追随 した。22〜14 nm 世代からは, 長年使用してきたプレー ナ構造のトランジスタを 3 次元 Triple-gate Fin FET 構造 (Intel は Tri-gate FET と呼んでいる) に替わった（Fig. 3 左)。このように, 微細化は, 構造や材料を変えること により, さらに性能を上げながら進行している。本稿の 冒頭でも述べたように, 先進半導体メーカーは $10 \mathrm{~nm}$
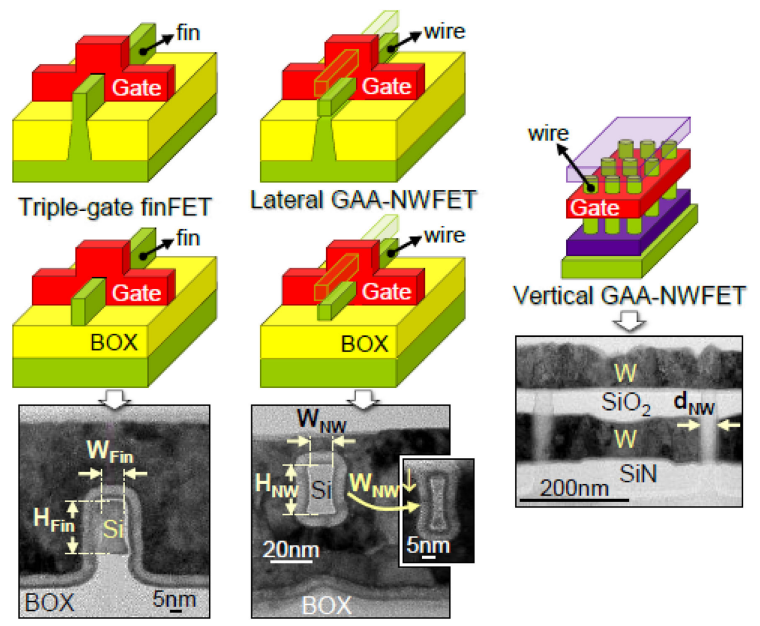

Fig. 3. (color online). Schematic drawing and TEM images taken across fins or wires on bulk or SOI substrates for the 3D device architectures ; triple-gate fin FETs (left), lateral gate-allaround (GAA) nanowire FETs (middle), and vertical GAA nanowire FETs (right). ${ }^{21)}$

プロセスで量産しており，今年は $10 \mathrm{~nm}$ の壁を破り，7 nm Fin FET プロセスを用いたロジックデバイスが生産 開始される見込みである。すでに $5 \mathrm{~nm}$ デバイスの試作 も行われている。 $5 \mathrm{~nm}$ よりもさらに微細化が進んだ世 代では, Fin FET から, MOS トランジスタのソース/ド レイン間のチャンネルをゲートが取り巻く構造のゲート オールアラウンド・ナノワイヤ (Gate All Around Nano Wire：GAA-NW）FET に替わらざるを得なくなる (Fig. 3 中央)。なぜなら，ショートチャンネル効果によ る待機時のリーク電流を抑止し, 動作時の電流駆動能力 を増すためである。電流駆動能力をさらに高めるために は，ナノワイヤを積層することになる。微細構造上それ が無理になったら，ナノワイヤを縦に並べて単位面積当 たりのトランジスタ数を増やす方向で対処することにな ろう (Fig. 3 右 $)^{21)}$ 。

ベルギーの先端半導体研究機関 IMEC (Interuniversity Microelectronics Centre）が公表している横型および縦型 ナノワイヤ FET の暫定的な製作プロセスフローの概 略を Table 2 に示す ${ }^{21)}$ ここでは, DHF (Dilute HF), Siconi $\left(\mathrm{NF}_{3} / \mathrm{NH}_{3} / \mathrm{H}_{2}\right.$ リモートプラズマ雲囲気下でのドラ イエッチングによる自然酸化膜除去, Table 1 参照), Clean などの文字がみられるが，それ以外の各工程の前 後に入る洗浄工程については, すべて記載が省略されて いる。次の工程に最適な表面状態を提供するための最適 な洗浄手法はこれから検討するところだが，材料口スも パターン倒壊もなく基板表面をクリーン化することは大 変挑戦的なテーマである。このプロセスフローは略字だ らけわかりにくいが, 詳しくは本稿著者による解説記 
Table 2. Simplified process flows for the fabrication of lateral gate-all-around nanowire FETs (upper) and that of vertical gate-all-around nanowire FETs (lower).

\begin{tabular}{|l|}
\hline \multicolumn{1}{|c|}{ Lateral GAA Nanowire FET } \\
-SOI substrate \\
-Si thinning +Fin pattern by I/Is + Anneal (JL only) \\
-Dummy-gate dielectric $\left(\mathrm{SiO}_{2}\right)$ deposition \\
-Channels doping \\
-Dummy a-Si dep+CMP+Gate patterning \\
-Extensions I/Is (only for some IM devices) \\
-Spacers +S/D SEG+HDDs I/Is + RTA \\
-CESL+ILD0 deposition/CMP \\
-Dummy-gate removal \\
-Fins release \\
-Gate stack deposition+metal-CMP \\
-S/D silicidation through vias in CESL/ILD0 \\
-CESL+ILD1+W-filled contacts \\
-BEOL process steps \\
\hline
\end{tabular}

\begin{tabular}{|c|}
\hline 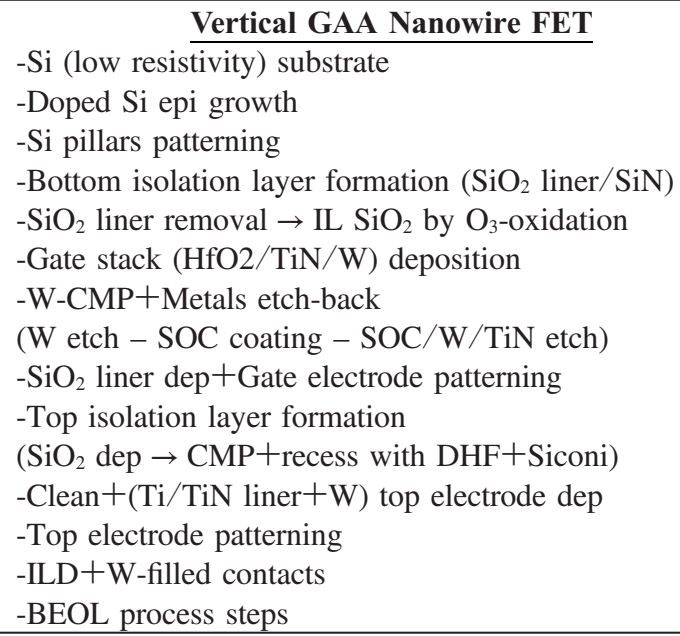 \\
\hline
\end{tabular}

事 ${ }^{22)}$ 参照されたい。

さらには, ある段階から, デバイス動作をもっと高速 化するため, チャンネル部分の基板材料も, 慣れ親しん だ Si からキャリア移動度の高い $\mathrm{Ge}$ や III-V 属化合物半 導体（GaInAs や InP など）へ替わろうとしている。こ のような Si にかわる基板材料の適切な洗浄手法の開発
も今後の課題である。

一方, 3D NAND フラッシュメモリ構造では, 上述の ピラー構造とは逆に, アスペクト比が大きな深溝を形成 しなければならない。均一な深掘りエッチング工程およ びその内壁の污染除去のための洗浄が歩留まり確保の点 で難関である。次世代メモリとしては, 磁気抵抗メモリ (MRAM), 相変化メモリ (PCRAM), 抵抗変化メモリ (ReRAM)，強誘電体メモリ（FeRAM）などさまざまな 不揮発性メモリが同時並行で研究されているが, いずれ も, 動作原理・構造・材料ともに新規性があり, それら に対応した最適精密洗浄が求められている。

\section{Si ウェーハ大口径化に向けた洗浄}

世界最先端半導体メーカー 5 社は, 量産で使用する $\mathrm{Si}$ ウェーハを $300 \mathrm{~mm}$ から $450 \mathrm{~mm}$ へと大口径化し, 面積 比で 2.25 倍増加させることにより, 半導体チップ当た りのコストダウンを図ろうとして, ニューヨーク州立大 学とともに Global 450 Consortium（G450C）を 2012 年 に設立し, $450 \mathrm{~mm}$ 半導体製造装置の評価とプロセス開 発を行ってきた。しかし, この間, 大口径化に向けて最 も熱心に活動していた Intel の PC 向けマイクロプロセッ サービジネスが失速してしまい, しかも, 各社とも大口 径化よりは微細化競争に注力しはじめたため, $450 \mathrm{~mm}$ 化は時期尚早ということで, G450Cも2016 年末に活動 を中止した。

G450C では, $450 \mathrm{~mm}$ 対応枚葉スピン洗浄装置に関し て初期の性能評価結果を公表しているので, その概要を 紹介する ${ }^{23)}$ 。

$300 \mathrm{~mm}$ ウェーハ洗浄装置（量産実績のある実用機） と $450 \mathrm{~mm}$ ウェー八洗浄装置 (試作機) でそれぞれ 3 種 類のレシピを用いて洗浄操作を行った際に新たに付着し たパーティクル数を Table 3 に示す ${ }^{23)}$ 。 $300 \mathrm{~mm}$ でのパ ーティクル数を 2.25 倍して面積を同じにして比較する と, $450 \mathrm{~mm}$ 装置の方がはるかにクリーンであることが わかる。このような操作を行わ前のデータでも 450

Table 3. Number of particles on $450 \mathrm{~mm}$ wafers added during wet cleaning on a $450 \mathrm{~mm}$ wafer alpha cleaning tool compared with a $300 \mathrm{~mm}$ wafer mature cleaning tool. ${ }^{21)}$

\begin{tabular}{|c|c|c|c|c|c|}
\hline \multirow{2}{*}{$\begin{array}{c}\text { Cleaning } \\
\text { Recipe }\end{array}$} & \multicolumn{3}{|c|}{$300 \mathrm{~mm}$ mature tool } & \multicolumn{3}{c|}{$450 \mathrm{~mm}$ alpha tool } \\
\cline { 2 - 6 } & $\geqq 45 \mathrm{~nm}$ & $\times 2.25$ & $\geqq 45 \mathrm{~nm}$ & $\geqq 38 \mathrm{~nm}$ & $\geqq 28 \mathrm{~nm}$ \\
\hline SC1-SC1NS & 8 & 18 & 4 & 6 & 10 \\
\hline SPM-SC1-SC1NS & 18 & 40 & 9 & 11 & 21 \\
\hline O3-DHF-SC1-SC1NS & 14 & 32 & 18 & 33 & 99 \\
\hline
\end{tabular}

$\mathrm{SC} 1=\mathrm{NH}_{4} \mathrm{OH} / \mathrm{H}_{2} \mathrm{O}_{2} / \mathrm{H}_{2} \mathrm{O}$ Mixture

$\mathrm{NS}=$ Nano-spray (atomizing jet spray)

$\mathrm{SPM}=\mathrm{H}_{2} \mathrm{SO}_{4} / \mathrm{H}_{2} \mathrm{O}_{2}$ Mixture

$\mathrm{O}_{3}=$ Ozonated Water

$\mathrm{DHF}=$ Dilute HF 
Table 4. Etching rate and micro-roughness after film strip for different films and chemicals on a $450 \mathrm{~mm}$ alpha single-wafer spin cleaning tool. ${ }^{21)}$

\begin{tabular}{|c|c|c|c|}
\hline \multirow{2}{*}{ Film } & Chemical & $\begin{array}{c}\text { Etching Rate } \\
(\mathrm{nm} / \mathrm{min})\end{array}$ & $\begin{array}{c}\text { Micro-roughness } \\
\text { Ra (nm) }\end{array}$ \\
\hline \multirow{5}{*}{$\mathrm{SiO}_{2}$} & $49 \% \mathrm{HF}$ & $>5000$ & 0.13 \\
\cline { 2 - 4 } & $\mathrm{DHF}$ & 378 & 0.12 \\
\cline { 2 - 4 } & $\mathrm{HF} / \mathrm{HNO}_{3}$ & 208 & 1.9 \\
\cline { 2 - 4 } & $\begin{array}{c}\mathrm{HF} / \mathrm{HNO}_{3} / \\
\mathrm{CH}\end{array} \mathrm{COOH}^{2}$ & 231 & 1.3 \\
\hline \multirow{2}{*}{$\mathrm{Si}_{3} \mathrm{~N}_{4}$} & $49 \% \mathrm{HF}$ & 513 & 0.15 \\
\cline { 2 - 4 } & $\mathrm{DHF}$ & 56 & 0.12 \\
\hline \multirow{2}{*}{$\mathrm{Poly}-\mathrm{Si} \mathrm{Hi}$} & $\mathrm{HF} / \mathrm{HNO}_{3}$ & 1338 & 1.7 \\
\cline { 2 - 4 } & $\begin{array}{c}\mathrm{HF} / \mathrm{HNO}_{3} / \\
\mathrm{CH} \mathrm{COOH}_{3}\end{array}$ & 1773 & 1.9 \\
\hline
\end{tabular}

$\mathrm{mm}$ の数值は $300 \mathrm{~mm}$ の数值と同等以上の良い結果を示 している。なお，洗浄の最後に DHF 処理して Si 表面の ケミカルオキサイドを除去し Si の地肌を露出させる, いわゆる HF-last レシピでは良い結果が出ておらず，今 後の課題としている。 $38 \mathrm{~nm}$ 未満の微小パーティクル除 去も今後の課題としている。

次に, DHF エッチング後のウェーハ面内エッチング 深さ均一性は, 当初は土2.5\%であったが, マルチノズ ルの採用で既に $+1.1 \%$ にまで改善した。 $300 \mathrm{~mm}$ 実用機 $\left( \pm 1.5 \%\right.$ 程度）よりも優れた均一性を実現できている ${ }^{23)}$

CVD 装置の評価で使用されたウェーハ上の各種被膜 を短時間でエッチングして再生利用するために，各種薬 液によりエッチングレートとマイクロラフネスを調べた 結果（Table 4）では，Si 酸化膜や窒化膜用には，エッ チングレートが大きく, ラフネスの小さな薬液組成を見 いだせたが，多結晶 Si については，ラフネスの小さな 薬液の開発が課題となっている ${ }^{23)}$ 。

$450 \mathrm{~mm}$ 大口径化対応半導体製造装置が試作され，単 結晶成長，ウェーハプロセスともに技術的には可能であ ることが実証されたが， $450 \mathrm{~mm}$ ウェーハの実用化は， デバイス微細化が極限に達する 2020 年代へ先送りされ る可能性が高い。そのころは, 数 $\mathrm{nm}$ 以下の超微小回路 パターンの倒壊を防止できるマテリアルロスのない洗浄 方法が必須で， $450 \mathrm{~mm}$ ウェーハ世代の大きな課題とな るであろう。

\section{6.お わりに}

半導体洗浄技術は, 変革期を迎えている。微細化競争 激化やEUV リソグラフィの実用化で，予想外のスピー ドで進む回路パターンの微細化，トランジスタの 3 次元 化, さらには GAA ナノワイヤ化, NAND フラッシュメ モリの 3 次元積層化，TSV（Through Silicon Via）を用
いた 3 次元実装などに対応するため，新たな洗浄・乾燥 手法が求められている。

$\mathrm{Si}$ よりもキャリア移動度の大きい III-V 属化合物半導 体を $\mathrm{Si}$ 基板上に選択エピタキシャル成長する検討も始 まっているが，エピタキシー前の表面状態は厳しく制御 する必要がある。そのための洗浄技術の確立が急務であ り，その表面状態を厳しく制御する必要がある。

2017 年 10 月に米国で開催された第 15 回半導体洗浄 科学技術国際シンポジウム（SCST15）でも，半導体製 造で今後ますます問題となる「パターン倒壊に関連した 諸問題とその対策」と次世代ロジック IC の高速化に採 用される予定の「 $\Gamma \mathrm{Ge}, \mathrm{SiGe}, \mathrm{III}-\mathrm{V}$ 属半導体の表面コン デイショニングとエッチング」が最大のセッションであ った。興味のある方は，同シンポジウム全論文集 ${ }^{24)}$ や会 議レビュー記事 ${ }^{25)}$ を参照されたい。

今後は，污染除去のための表面洗浄だけではなく， むしろ原子レベルでの最適表面状態制御（Surface Conditioning）や次の工程への最適表面の提供（Surface Preparation）がナノデバイスでは重要度を増すであろう。 地球環境にする負荷低減も強く求められている。

デバイスメーカー, 装置メーカー, 薬材メーカー, お よびアカデミアの相互協力により，半導体洗浄技術（む しろ表面状態制御技術と呼ぶべきだろう）の今後の進展 が期待される。

\section{文献}

1) 服部 毅：「TSMC が 2 位以下に大差をつけて首 位を堅持 - 2017 年のファウンドリランキング」, マ イナビニュース, 2017.11.30. (https://news.mynavi.jp/ article/20171130-550195/) (最終アクセス 2017 年 12 月 6 日)

2) 服部 毅：「2017 年第 3 四半期の NAND 市場は スマホ/サーバの需要増で前四半期比 $14.3 \%$ 増」, マ イナビニュース, 2017.11.28. (https://news.mynavi.jp/ article/20171128-548704/) (最終アクセス 2017 年 12 月 6 日)

3) T. Hattori (ed.) : "Ultra Clean Surface Processing of Silicon Wafers," (Springer, Heidelberg/Berlin/New York, 1998).

4) 服部 毅編 : 新編シリコンウェーハ表面のクリーン 化技術 (リアライズ社, 東京, 2000).

5) 服部 毅 : 空気清浄, 48(6), 30 (2011).

6) 服部 毅 : 表面技術, 59, 526 (2008).

7) T. Hattori : ECS J. Solid State Sci. Technol. 3, N3014 (2014).

8) T. Hattori : "Development of Surface Contamination and Cleaning Volume 9", ed. by R. kohli and K. Mittal (Elsevier, Amsterdam/New York, 2017) p. 1.

9) T. Hattori, H. Hirano, T. Osaka and H. Kuniyasu : IEEE Trans. Semicond. Manuf. 20(3), 252 (2007). 
10) 服部 毅 : 日本混相流学会誌 24(1), 13 (2010).

11）近藤英一編：“半導体・MEMS のための超臨界流体” (コロナ社, 2012).

12) T. Watanabe, T. Toshima, M. Nakamori, K. Egashira, Y. Ido, N. Matsumoto and T. Orii : "Semiconductor Cleaning Science and Technology 13", ed. by T. Hattori, ECS Trans. 58(6), 191 (2013).

13) H. Chen, S. Verhaverbeke, R. Gouk, K. Leschkies, S. Sun, N. Bekiaris and R. Visser : "Semiconductor Cleaning Science and technology 14", ed. by T. Hattori, ECS Trans. 69(8), 119 (2015). 69(8), 119 (2015).

14) 服部 毅: 表面技術 61, 578 (2010).

15) 服部 毅：マイナビニュース, 2017.3.07 付. (http:// news.mynavi.jp/articles/2017/03/07/semes/) (最終アク セス 2017 年 12 月 6 日)

16) H. Saito, A. Munakata, D. Ichishima, T. Yamanishi, A. Okamotgo, K. Saga, H. Kuniyasu and T. Hattori : ECS Proceedings Series, PV2003-26, 289 (Electrochemical Society, U.S.A., 2003).

17) K. Dobashi, K. Inai, M. Saito, T. Seki, T. Aoki and J. Matsuo : IEEE Trans. Semicond. Manuf. 26, 328
(2013).

18) 服部 毅 : 産業洗浄, No.10, 26 (2012).

19）服部 毅：“エレクトロニクス洗浄技術” (技術情報 協会, 2007) p. 148.

20) 服部毅：月刊 Electronic Journal, 2015 年 2 月号, p. 58.

21) A. Veloso : "Semiconductor Cleaning Science and Technology”, ed. by T. Hattori, ECS Trans., 80(2), 3 (2017).

22) 服部毅：マイナビニュース, 2016.6.27. (http:// news.mynavi.jp/articles/2016/06/27/vlsisymposia2016_ imec/) (最終アクセス 2017 年 12 月 6 日)

23) B. Yu, F. Ku, C. Taft, A. Laerra, J. Lin, T. Hayashi, A. Morita, K. Arai and H. Naohara : "Semiconductor Cleaning Science and Technology 13", ed. by T. Hattori, ECS Trans. 58(6), 87 (2013).

24) T. Hattori (ed.) : "Semiconductor Cleaning Science and Technology 15”, ECS Trans. 80(2), (2017).

25) 服部 毅: マイナビニュース, 2016.11.06. (http:// news.mynavi.jp/series/scst15/001/) (最終アクセス 2017 年 12 月 6 日) 